\title{
Tolerance of Cowpea (Vigna unguiculata (L) ) Varieties N- fixing Ability to Application of Cow dung combined with NPK 20-10-10.
}

\author{
Olatunji, $\mathrm{O}^{1^{*}}, \mathrm{~A} . \mathrm{Ali}^{2}$ and N.B Ibrahim ${ }^{3}$ \\ (1,2,3) Department of soil science university of agriculture, P.M.B 2373, makurdi. Benue State, Nigeria.
}

\begin{abstract}
In 2008 and 2009 cropping season, field experiments were conducted to determine the effects that the combined cow dung and NPK 20-10-10 had on both the nodule count and N-fixing ability of two varieties of cowpea (ITAS EARLY and IAR 1060). The treatments were: cow dung $\left(0,4,8 \mathrm{tha}^{-1}\right) ; \mathrm{NPK} 20-10-10$ fertilizer $\left(0,150\right.$ and $\left.300 \mathrm{~kg} \mathrm{ha}^{-1}\right)$. Treatments were combined pair-wise to give nine treatments combinations. The experiments were laid-out in a randomized complete block design (RCBD) with three replications. Each experimental plot measured $3 \mathrm{~m} \times 4 \mathrm{~m}$ with an alley of $1 \mathrm{~m}$ between blocks and $0.5 \mathrm{~m}$ between plots. Four seeds were planted per hole at $25 \mathrm{~cm}$ plant to plant distance in a maize mixture and later thinned to two plants per stand at two weeks after planting (2 WAP). This gave a total plant population of about 80,000 plants per hectare. The nodule count and $N$-fixed were determined 3, 6 and 12 weeks after planting (WAP). The combination of cow dung and NPK 20-10-10 contributed to the differences $(P<0.05)$ in number of count obtained per plant of cowpea as well as the amount of $N$-fixed in the experiment. The high rate of cow dung and high rate of NPK 20-10-10 did not lead to increase in N-fixed by the cowpea varieties. The highest nodules (82.4 and 88.4) and $\mathrm{N}$-fixed (38.65 and $42.51 \mathrm{~kg} \mathrm{ha}^{-1}$ ) for 2008 and 2009 respectively were obtained the sole application of $8 \mathrm{tha}$ ho cow dung without NPK 20-10-10 fertilizer application on cowpea variety, ITAS EARLY. The result of the study shows that cowpea variety ITAS EARLY tolerated high nutrient combinations better than cowpea IAR 1060 in terms of $N$-fixing ability.
\end{abstract}

Keywords: $N$-fixing ability, Tolerance, cow dung application and nodulation.

\section{Introduction}

Biological Nitrogen Fixation (BNF) involves the conversion of molecular nitrogen gas $\left(\mathrm{N}_{2}\right)$ into ammonia through a biological process. (Cheng, 2008). BNF is the major source of fixed $\mathrm{N}$ for plant life. Estimates of global BNF ranges from 100 to 290 million tonnes of N / year. Cheng, 2008. Of this total, 40 to 48 million tones was estimated to be biologically fixed in agricultural crops and fields. Herbaceous and leguminous cover crops provide sufficient $\mathrm{N}$ inputs through BNF to meet the needs of subsequent maize crops. In Africa, the main species used are of the genus mucuna, crotolari, pueraria, Dolicho and Desmodium (Balasubramanian and Blaise, 1993; Wortmann et al., 1994).

The use of mucuna in short-term fallows interplanted with maize or planted during the dry season was common in Benin and Ghana (Osei-Bosisu and Buckles, 1993; Manyong et al., 1997). Mucuna fixes $\mathrm{N}$ and smoothers imperata (Imperata cylindrical (L) Rausch. (IITA, 1995). Leguminous fallows, because of their shorter duration and lower biomass accumulation provides $\mathrm{N}$ inputs to the soil at a faster rate. (Szott et al., 1998). Leguminous fallows, therefore, provide excellent options for $\mathrm{N}$ biologically, provided that the soil is sufficient in P and that farmers are willing to make land available for crop - fallow rotations. (Galiba et al, 1997; Kwesiga et al., 1998).

Intercropping of grain legumes generality results in the legume deriving a greater proportion of its $\mathrm{N}$ from $\mathrm{N}_{2}$ fixation than when grown alone (Namibiar et al.,1983). Cowpea intercropping is advantageous when intercropped with maize or millet in seasons with adequate rainfall, but the cowpea cowpea competing strongly with the cereal crop for soil water when rainfall was limiting (Shumba et al., 1990; Franzluebbers et al.,1994).

Cropping systems as observed by Bationo et al. (2003) affects fertilizer use efficiency Tolerance of cowpea species to high fertilizer application will determine their involvement in cowpea /cereals intercropping systems, because cereals require more nutrient inputs in terms of nitrogen, phosphonus and potassium.the earlier work of Olatunji and Anjembe, 2011 reported the effect of enriched poultry manure with mineral fertilizers nodulation and $\mathrm{N}$-fixing ability of cowpea.

This research work was designed to further investigate the tolerance of two cowpea species to combined application of cow dung and NPK 20-10-10 fertilizer in maize mixtures. 


\section{Material And Methods}

Site

The field experiments were conducted at the experimental farm of the University of Agriculture, Makurdi $\left(7^{0} 41^{\prime} \mathrm{N}, 8^{\circ} 35^{\prime} \mathrm{E}\right)$ in the southern guinea agro-ecological zone of Nigeria. The soil used was classified as typic ustropept.

\section{Field experiment}

The experiments were conducted during the 2008 and 2009 cropping seasons and were laid out in a randomized complete block design with three replications.

The plot size was $4 \mathrm{~m}$ × $3 \mathrm{~m}$ (four ridges per plot)

The treatments (9) were as follows:

$\mathrm{CD}_{0} \mathrm{~F}_{0}-$ Control

$\mathrm{CD}_{0} \mathrm{~F}_{1}-150 \mathrm{~kg} \mathrm{ha}^{-1}$ NPK 20-10-10

$\mathrm{CD}_{0} \mathrm{~F}_{2}-300 \mathrm{~kg} \mathrm{ha}^{-1}$ NPK 20-10-10

$\mathrm{CD}_{1} \mathrm{~F}_{0}-4 \mathrm{t}$ ha $-{ }^{1}$ cow dung

$\mathrm{CD}_{1} \mathrm{~F}_{1}-4 \mathrm{t} \mathrm{ha}^{-1}$ cow dung $+150 \mathrm{~kg} \mathrm{ha}^{-1} \mathrm{NPK} 20-10-10$

$\mathrm{CD}_{1} \mathrm{~F}_{2-} 4 \mathrm{t} \mathrm{ha}^{-1}$ cow drug $+300 \mathrm{~kg} \mathrm{ha}^{-1}$ NPK 20-10-10

$\mathrm{CD}_{2} \mathrm{~F}_{0}-8 \mathrm{tha}^{-1}$ cow drug

CD2 F1 - $8 \mathrm{tha}^{-1}$ cow drug $+150 \mathrm{~kg} \mathrm{ha}^{-1}$ NPK 20-10-10

$\mathrm{CD}_{2} \mathrm{~F}_{2}-8 \mathrm{tha}^{-1}$ cow dung $+300 \mathrm{~kg} \mathrm{ha}^{-1}$ NPK 20-10-10

The sites were manually cleared using cutlass and later ridged with hoe. Cow dung as a sole treatment and half of NPK 20-10-10 (150 Kg ha ${ }^{-1}$ and $\left.300 \mathrm{Kg} \mathrm{ha}^{-1}\right)$ combined with cow dung (4 and $8 \mathrm{tha}^{-1}$ ) were uniformly spread on top of the ridge $(0.75 \mathrm{~m}$ apart $)$ and incorporated into the soil with hoe two weeks before planting. Planting was done in the month of August for the two seasons. Four cowpea seeds (two varieties: ITAS EARLY and IAR 1060) were panted $25 \mathrm{~cm}$ plant to plant distance in a maize mixture and later thinned to two plants per stand at two weeks after planting ( 2 WAP ), this gave a total population of 80,000 plants per hectare.

\section{Soil sampling, soil and cow dung analysis.}

Before planting in 2008 surface $(0-15 \mathrm{~cm})$ soil samples were collected from 8 points and bulked the soil samples and cow dung applied were analyzed. The soil samples and the cow dung sample were air- dried, crushed and allowed to pass through $2 \mathrm{~mm}$ serve. Particle size distribution was carried out using Hydrometer method (Bouyoucos, 1951), while $\mathrm{pH}$ was measured with glass electrode $\mathrm{pH}$ in soil solution ratio of 1:2 in $0.01 \mathrm{M} \mathrm{CaCl} \mathrm{Ca}_{2}$-Soil organic carbon (OC) was determined using the Walkey- Black (1934) method and the total $\mathrm{N}$ by the micro - kjeldahl digestion method (Bremner and Mulvaney, 1982) after digestion of samples with concentrated $\mathrm{H}_{2} \mathrm{SO}_{4}$.. Available $\mathrm{P}$ was determine using I:N NH $\mathrm{NAC}_{4} \mathrm{OAlution}$ with $\mathrm{K}$ and $\mathrm{Na}$ read using flame photometer, while $\mathrm{Ca}$ and $\mathrm{Mg}$ were determined on the atomic absorption spectrophotometer. Cation exchange capacity $\{\mathrm{CEC}\}$ was established as summation the excheageable cations $\{\mathrm{K}, \mathrm{Na}, \mathrm{Ca}$ and $\mathrm{Mg}\}$. The cow dung used for the experiment was collected from the University of Agriculture, Makurdi Farm unit in wet form and later dried.

The nitrogen of the cow dung sample was determined using micro- kjekdahl method. For the determination of $\mathrm{P}, 5 \mathrm{ml}$ of the sample solution from wet digestion was used. Phosphorus was determined using vanado- Molybdate colorimetry method. The $\mathrm{K}, \mathrm{Ca}$ and $\mathrm{Na}$ in the sample was determined using flame was determined using Atomic Absorption spectrometer (ASS).

\section{Crop sampling}

Destructive samplings were carried out on both cowpea varieties and maize in the control plot at 3 week after planting, 6 weeks after planting ( 6 WAP), and at harvest to determine amount of N- fixed by cowpea. From each plot cowpea plants were carefully up rooted with hoe to the rooting depth and taken to the laboratory. The nodules were counted, then $\mathrm{N}$ in leaves, shoot and roots were determined. The maize plant in the control plot was up rooted at each sampling period to serve as non- fixing reference crop.

\section{Plant Tissue Analysis}

Cowpea plants and maize that were uprooted at $3 \mathrm{WAP}, 6 \mathrm{WAP}$ and harvest, the leaves, shoot and roots were ground after over dried at $110^{\circ} \mathrm{C}$ for 24 hours using mortar and pestle. The materials were sieved using 40- mesh screen after which they were subjected to analysis. Total plant nitrogen are was determined using micro kjeldahl method. 


\section{Estimation of N.fixed by cowpea}

Estimation of nitrogen fixed was determined using equation described by Hauser (1990) called extended $\mathrm{N}$ difference method. Estimates of fixed nitrogen are calculation by this equation.

$\mathrm{N}$. fixed $=\mathrm{N}($ cowpea $)-\mathrm{N}$ ref (maize)

The $\mathrm{N}$ in leares, root of legumes and reference crop are included in consideration of the total $\mathrm{N}$ fixed.

\section{Data Analysis}

The statistical analysis was performed using SPSS statistical package for the analysis of variance multiple range test (DMRT) at 0.05 level of probability where F. ratio was significant.

\section{Results}

\section{Cow dung and soil properties}

The cow dung contained $11.8 \% \mathrm{C}, 1.42 \% \mathrm{~N}, 1.45 \% \mathrm{P}, 1.55 \% \mathrm{~K}, 8.50 \% \mathrm{Ca}$ and $0.75 \% \mathrm{Mg}$. The physical and chemical properties of the soil on which the experiments were carried out are shown in Table 1.

The soil was sandy loam, slightly acidic and very low in organic $\mathrm{C}$, the total $\mathrm{N}$ was very low and the available $\mathrm{P}$ and exchangeable $\mathrm{K}$ values were low for the production of maize, but cowpea can tolerate the prevailing soil conditions.

\section{Nodules Count of cowpea variety (ITAS EARLY)}

The application of cow dung and NPK 20-10-10 fertilizer have positive effect in the differences in number of nodules count obtained per plant of cowpea variety (ITAS EARLY) in 2008 and 2009 (Figure 1). The highest nodules count was obtained at 6 WAP which correspond to the full bloom period of the cowpea physiological growth. The least nodules count was obtained at 3 WAP. The data obtained at 12 WAP was more than 3 WAP but less than 6 WAP. In 2008 at 6 WAP the highest average nodules count was obtained from $8 \mathrm{t}$ ha- $^{1}$ cow dung (82.3), this was followed by $4 \mathrm{tha}^{-1}$ cow dung (61.6) and the third highest was obtained from $4 \mathrm{t}$ $\mathrm{ha}^{-1}$ cow dung $+300 \mathrm{Kg} \mathrm{ha}{ }^{-1}$ NPK 20-10-10 (46.9). The data collected in 2009 followed the same trend with variation in the numbers observed. The highest nodules count obtained from $8 \mathrm{t} \mathrm{ha}^{-1}$ cow dung (88.4), followed by $4 \mathrm{tha}^{-1}$ cow dung (72.5) and the third highest obtained from $4 \mathrm{t} \mathrm{ha}^{-1}$ cow dung $+300 \mathrm{Kg} \mathrm{ha}^{-1} \mathrm{NPK} 20-10-10$ (52.6) in both year of the study the control had the least count 18.6 and 25.2 for 2008 and 2009 respectively.

\section{Nodules count of cowpea variety (1AR 1060).}

The effect of the cow dung and NPK 20-10-10 on the nodules count per plant of cowpea (IAR1060) is shown in (figure 2)

Table 1: Soil physical and chemical properties before planting

\begin{tabular}{|c|c|}
\hline Properties & Values \\
\hline $\mathrm{pH}\left(\mathrm{H}_{2} \mathrm{O}\right)$ & 6.20 \\
\hline $\mathrm{pH}\left(\mathrm{CaCl}_{2}\right)$ & 5.90 \\
\hline sand & 756.0 \\
\hline Silt & 172.0 \\
\hline Clay & 72.0 \\
\hline Textural Class & Sandy loam \\
\hline $\mathrm{N}(\mathrm{g} \mathrm{Kg}-1)$ & 0.09 \\
\hline $\mathrm{P}(\mathrm{mg} \mathrm{Kg}-1)$ & 2.15 \\
\hline $\mathrm{K}(\mathrm{c}$ mol Kg-1) & 0.22 \\
\hline $\mathrm{Ca}(\mathrm{c}$ mol Kg-1) & 2.60 \\
\hline $\mathrm{Mg}(\mathrm{c}$ mol Kg -1$)$ & 2.48 \\
\hline $\mathrm{Na}$ (c mol Kg-1) & 0.31 \\
\hline $\mathrm{CEC}$ (c mol Kg-1) & 6.48 \\
\hline $\mathrm{OC}(\mathrm{g} \mathrm{Kg}-1)$ & 1.25 \\
\hline $\mathrm{OM}(\mathrm{g} \mathrm{Kg}-1)$ & 1.45 \\
\hline
\end{tabular}

A significant response was equally observed in the average nodules count per plant as was observed for cowpea (1TAS ESRLY). The data obtained under variety (1AR 1060) was smaller compared to variety (ITAS EARLY). It was observed that at 3 WAP in 2008 treatments $150 \mathrm{~kg} \mathrm{ha}^{-1}$ NPK 20-10-10 and no nodules per plant. 
In 2008 at 6 WAP the highest average number of nodules was obtained from $8 \mathrm{t} \mathrm{ha}^{-1}$ cow dung (49.1) this was followed by $4 \mathrm{t} \mathrm{ha}^{-1}$ cow dung (43.2) and he third highest obtained from $4 \mathrm{t} \mathrm{ha}^{-1}$ cow dung $+300 \mathrm{Kg} \mathrm{ha}^{-1} \mathrm{NPK}$ 20-10-10. In 2009 at 6 WAP the highest nodules count was obtained from $8 \mathrm{t} \mathrm{ha}^{-1}$ cow dung (57.6), followed from $8 \mathrm{t} \mathrm{ha}^{-1}$ cow dung (51.3) and the third highest obtained from $4 \mathrm{t} \mathrm{ha}^{-1}$ cow dung $+300 \mathrm{Kg} \mathrm{ha}^{-1} \mathrm{NPK} 20-10$ 10 (150.8). The least nodules count for 2008 and 2009 was obtained from treatment $150 \mathrm{Kg} \mathrm{ha}^{-1}$ NPK 20-10-10 with nodules count of 16.3 and 23.6 for 2008 and 2009 respectively.

\section{N- fixed by cowpea variety (ITAS EARLY)}

The application of cow dung and NPK 20-10-10 fertilizer have positive impact in the amount of Nfixed by cowpea variety (ITAS EARLY) in 2008 and 2009 (figure 3) there are obvious correlation between the nodules count observed and the amount of N-fixed. It was observed at 3 WAP in 2008 that there were no NFixed from treatment $150 \mathrm{Kg} \mathrm{ha}^{-1} \mathrm{NPK} 20-10-10$ and $300 \mathrm{Kg} \mathrm{ha}^{-1} \mathrm{NPK} 20-10-10$. The $\mathrm{N}$ - fixed at 6 WAP was the highest across the treatment in both years. In 2008 the highest $\mathrm{N}$-fixed was obtained from $8 \mathrm{t} \mathrm{ha}^{-1}$ cow dung

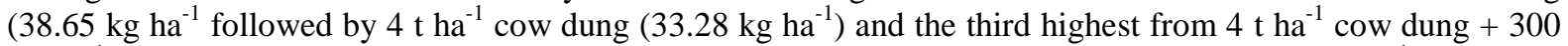
$\mathrm{kg} \mathrm{ha}^{-1}$ NPK 20-10-10. While in 2009 at 6 WAP the highest $\mathrm{N}$ - Fixed was obtained from $8 \mathrm{t} \mathrm{ha}^{-1} \mathrm{cow}$ dung $\left(42.51 \mathrm{~kg} \mathrm{ha}^{-1}\right)$ the third highest was obtained from $4 \mathrm{tha}^{-1}$ cow dung

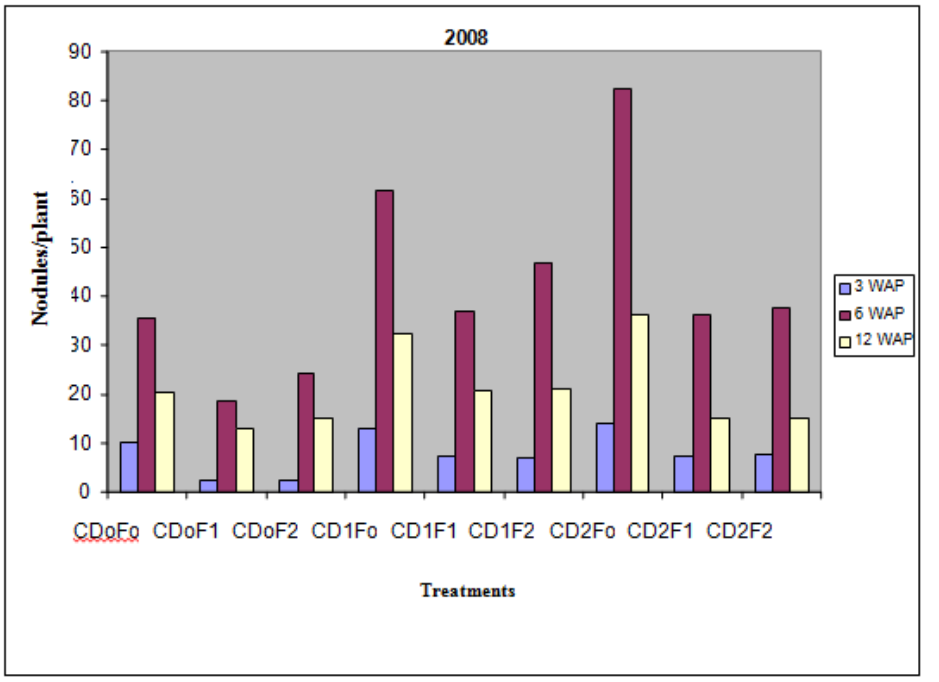

Key: CD - cow dung $\left(0,1\right.$, and $2-0 \mathrm{t}, 4 \mathrm{t}$ and $\left.8 \mathrm{tha}^{-1}\right)$

F- NPK 20-10-10 (0, 1 and 2- $0 \mathrm{Kg}, 150 \mathrm{Kg}$ and $\left.300 \mathrm{Kg} \mathrm{ha}^{-1}\right)$

Figure 1: Effect of Cow Dung and NPK 20-10-10 on nodule counts per plant of cowpea (ITAS EARLY) 2008 and 2009

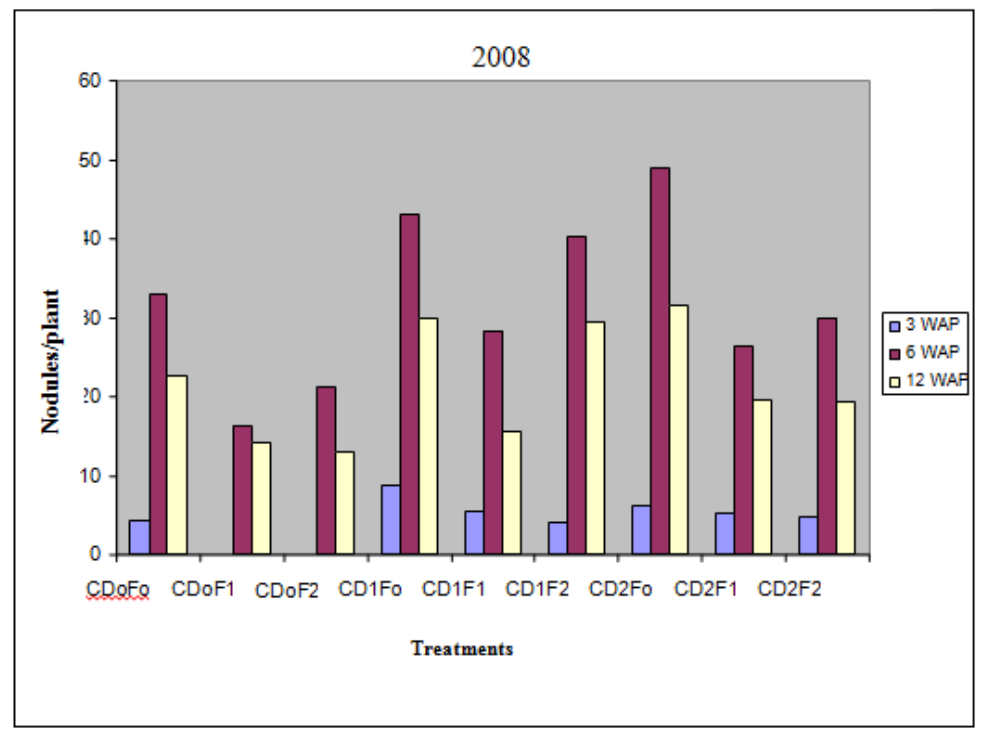




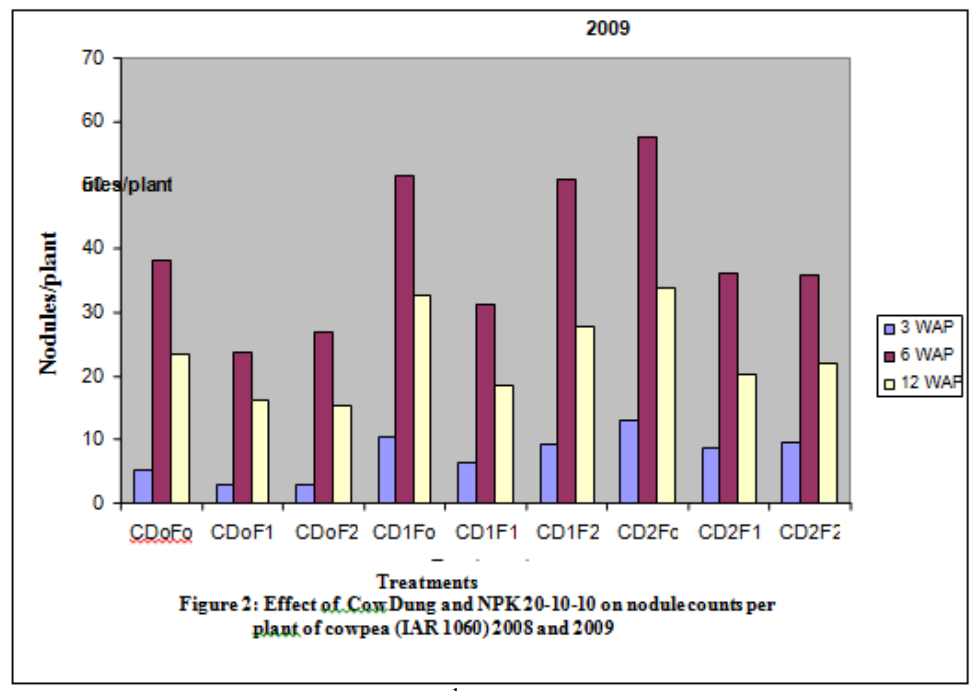

Key: $\mathrm{CD}-$ cow dung $\left(0,1\right.$, and $2-0 \mathrm{t}, 4 \mathrm{t}$ and $\left.8 \mathrm{t} \mathrm{ha}^{-1}\right)$

F- NPK 20-10-10 (0, 1 and 2- $0 \mathrm{Kg}, 150 \mathrm{Kg}$ and $\left.300 \mathrm{Kg} \mathrm{ha}^{-1}\right)$

$+300 \mathrm{~kg} \mathrm{ha}^{-1} \mathrm{NPK} 20-10-10\left(31.70 \mathrm{~kg} \mathrm{ha}^{-1}\right)$. The least $\mathrm{N}$ - fixation was obtained from treatment $300 \mathrm{~kg} \mathrm{ha}^{-1} \mathrm{NPK}$ 20-10-10 for both years $14.06 \mathrm{ha}^{-1}$ and $21.61 \mathrm{~kg} \mathrm{ha}^{-1}$ for 2008 and 2009 respectively.

\section{$\mathrm{N}$-fixed by cowpea variety (IAR 1060)}

The effect of combined application of cow dung and NPK 20-10-10 is presented in (figure 4). As earlier observed under cowpea variety (ITAS EARLY) that there is relationship between nodules count observed and $\mathrm{N}$-fixed, the observation remained valid. However, the amount $\mathrm{N}$-fixed under cowpea variety (IAR 1060) is lower that what was obtained from variety (ITAS EARLY). In 2008 at 6 WAP the highest Nfixed was obtained from treatment $8 \mathrm{t} \mathrm{ha}^{-1}$ cow dung $\left(34.63 \mathrm{~kg} \mathrm{ha}^{-1}\right)$, followed by treatment $4 \mathrm{t} \mathrm{ha}^{-1}$ cow dung $300 \mathrm{~kg} \mathrm{ha}^{-1}$ NPK 20-10-10 $\left(29.90 \mathrm{~kg} \mathrm{ha}^{-1}\right)$, the third highest was obtained from $4 \mathrm{t} \mathrm{ha}^{-1}$ cow dung $\left(29.15 \mathrm{~kg} \mathrm{ha}^{-1}\right)$. In 2009 at 6 WAP the highest $\mathrm{N}$-fixed was obtained from treatment $8 \mathrm{t} \mathrm{ha}^{-1}$ cow dung $\left(34.65 \mathrm{~kg} \mathrm{ha}^{-1}\right)$, followed by treatment $4 \mathrm{t} \mathrm{ha}^{-1}$ cow dung $+300 \mathrm{~kg} \mathrm{ha}^{-1}$ NPK 20-10-10 $\left(33.10 \mathrm{~kg} \mathrm{ha}^{-1}\right)$ and the third highest from $4 \mathrm{t} \mathrm{ha}^{-1}$ cow dung $\left(32.70 \mathrm{~kg} \mathrm{ha}^{-1}\right)$. In both years, the least $\mathrm{N}$ - fixed was obtained from treatment $150 \mathrm{~kg} \mathrm{ha}^{-1}$ for 2008 and 2009 respectively.

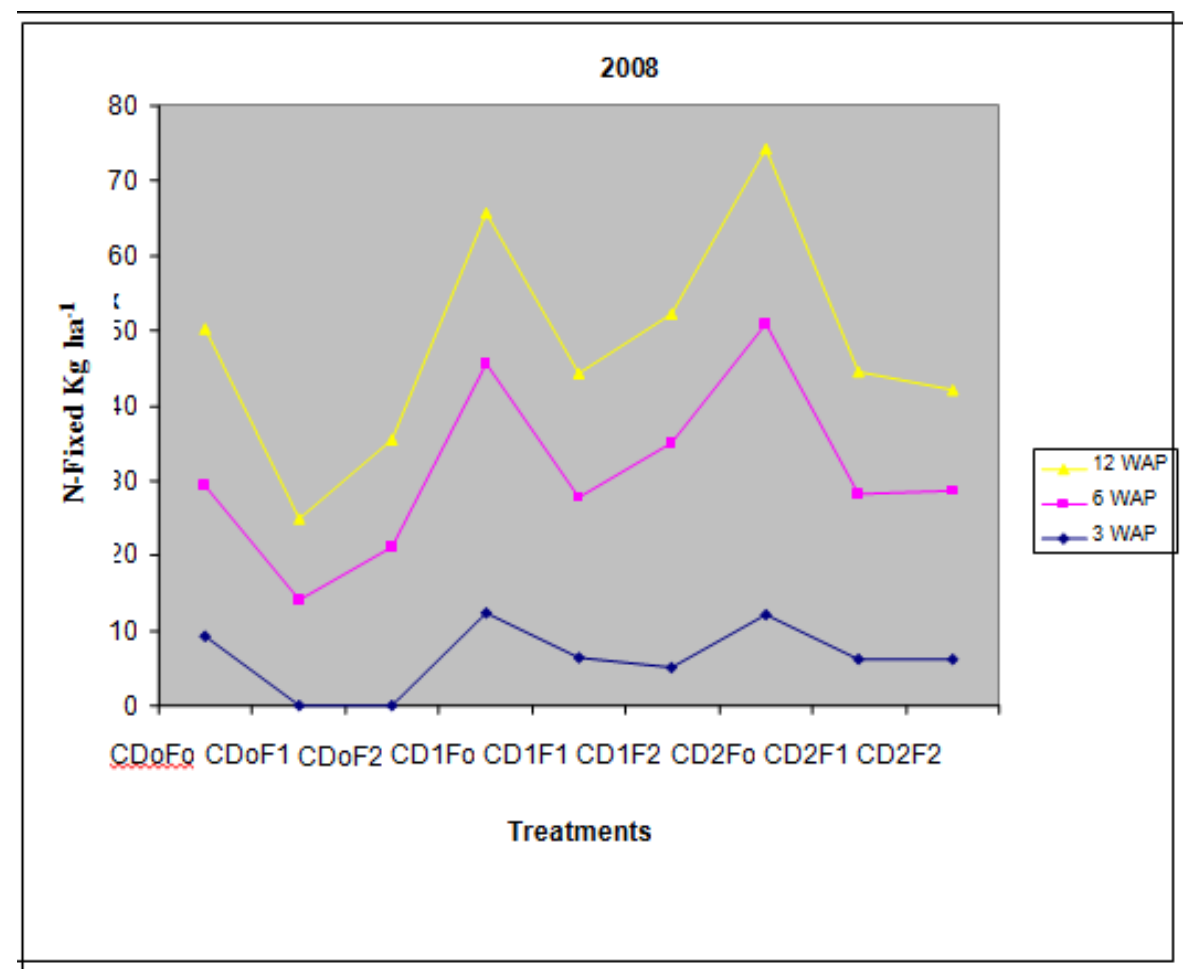




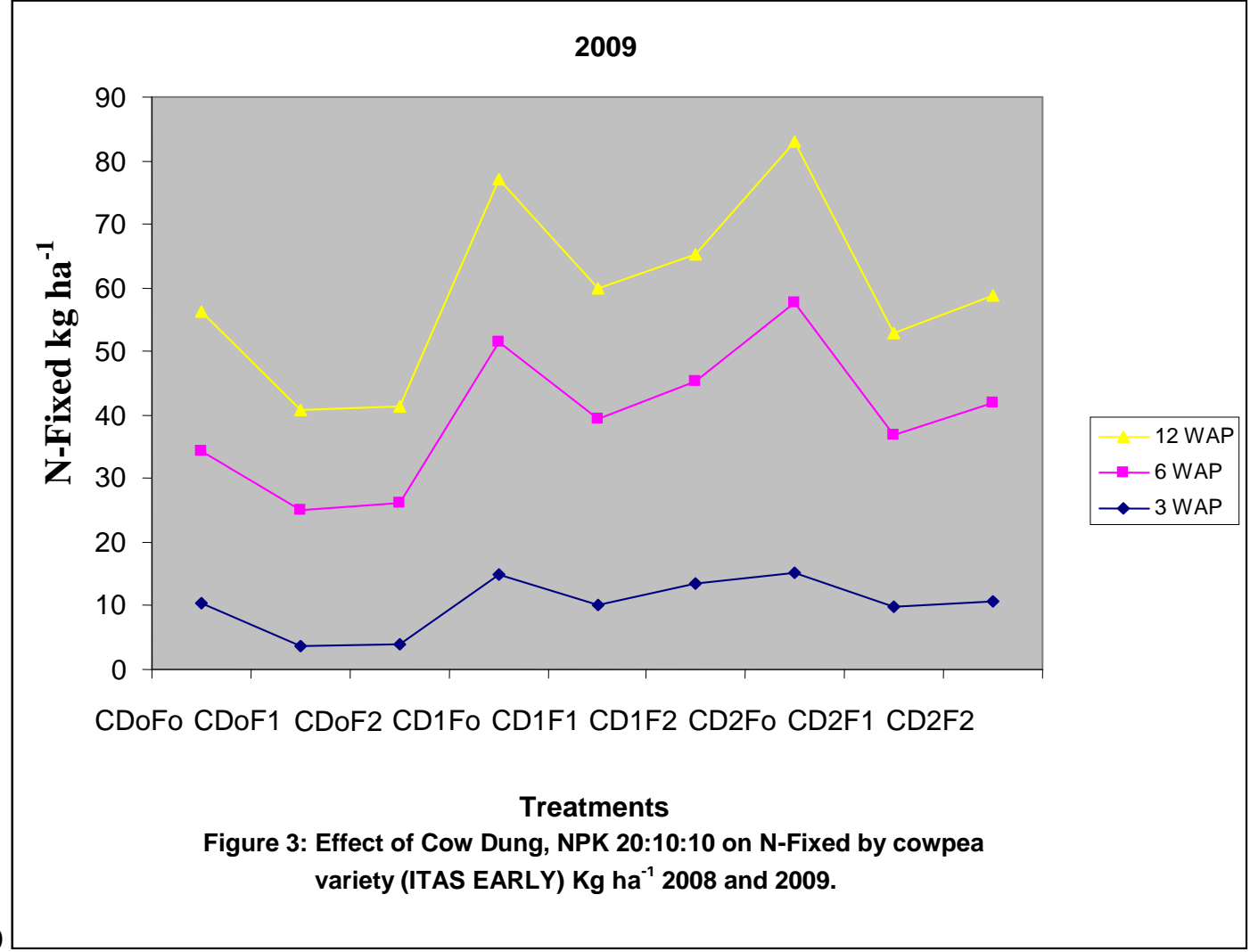

Key: CD - cow dung $\left(0,1\right.$, and $2-0 \mathrm{t}, 4 \mathrm{t}$ and $\left.8 \mathrm{t} \mathrm{ha}^{-1}\right)$

F- NPK 20-10-10 (0, 1 and 2- $0 \mathrm{Kg}, 150 \mathrm{Kg}$ and $\left.300 \mathrm{Kg} \mathrm{ha}^{-1}\right)$

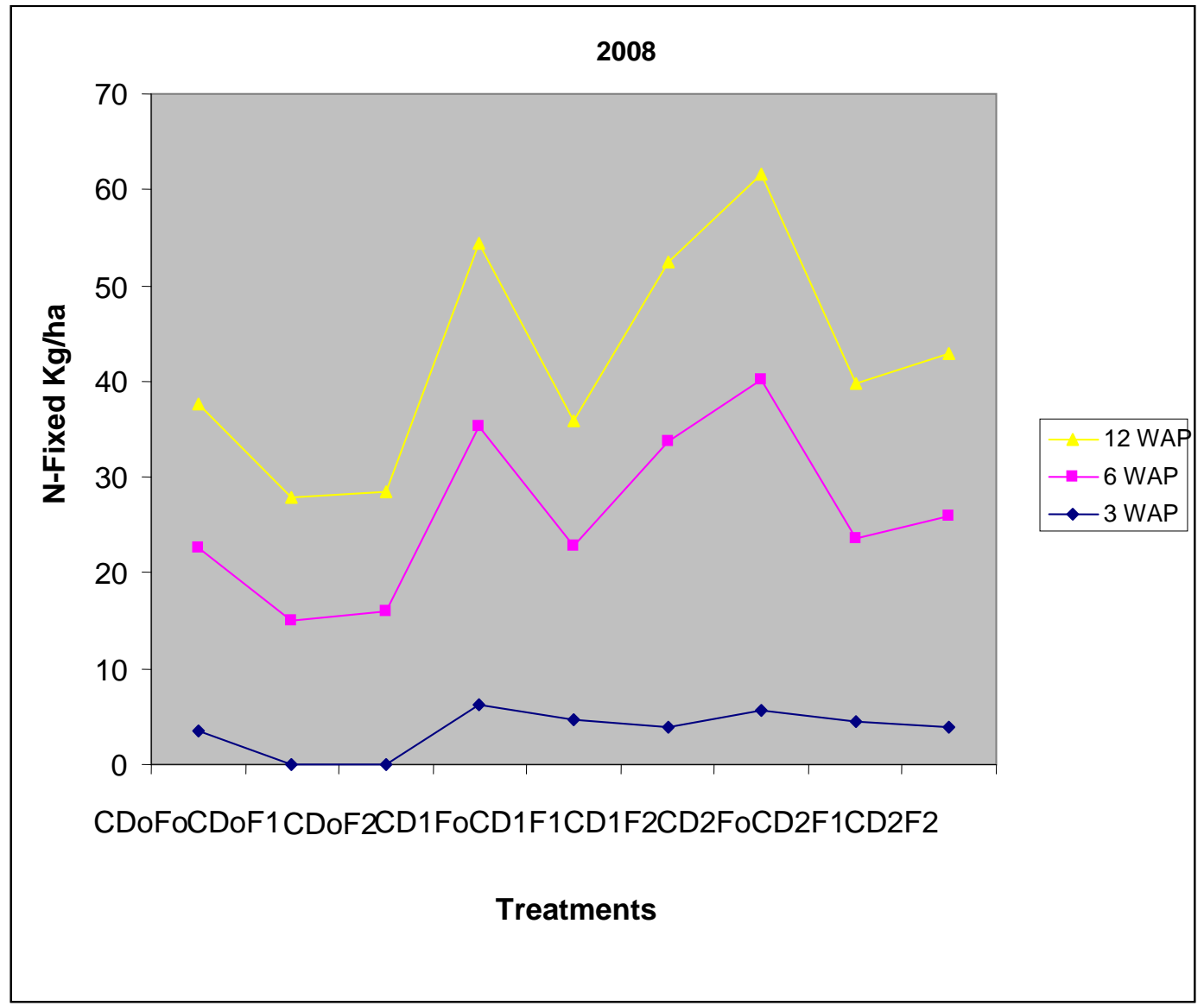




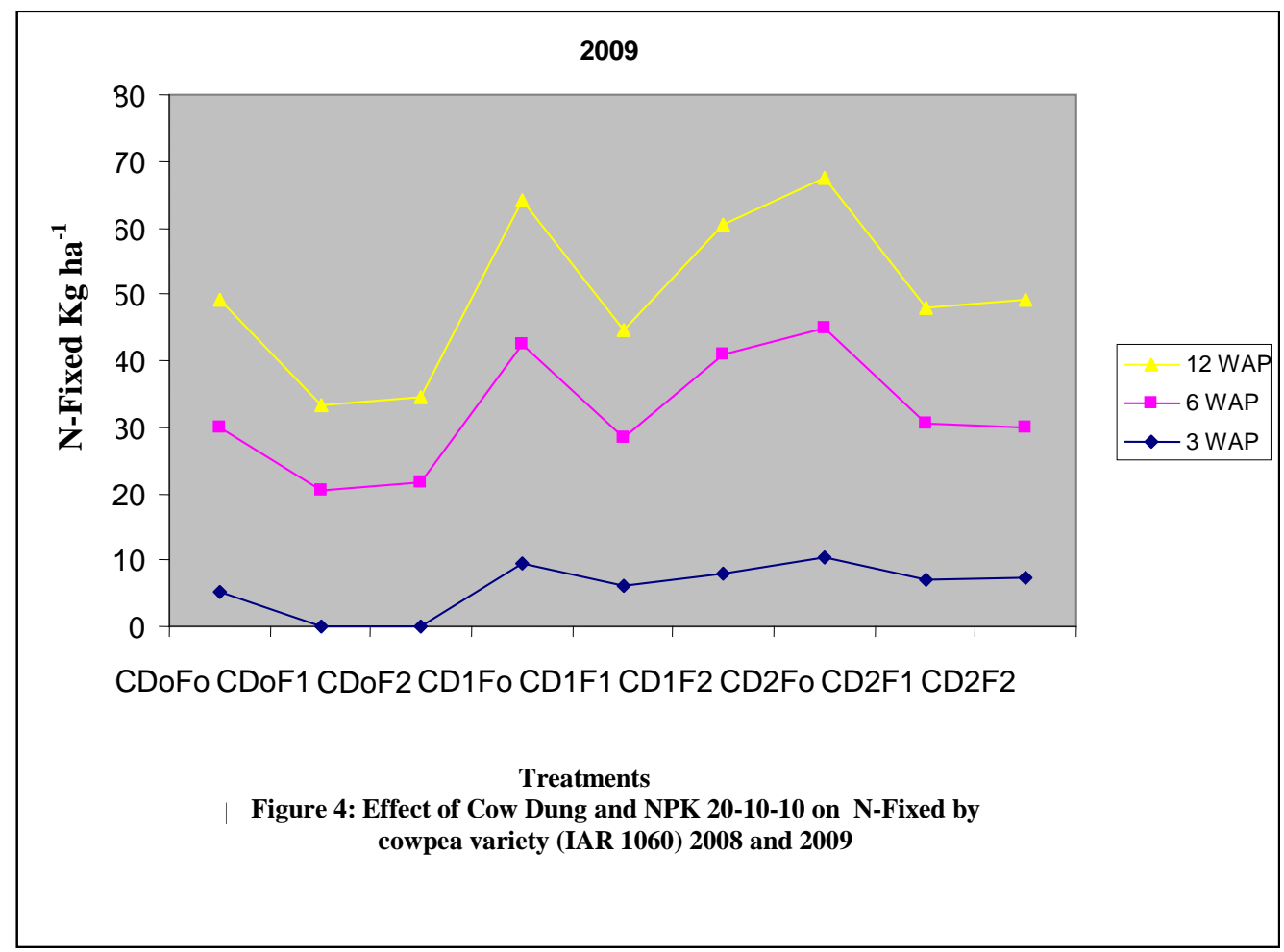

Key: $\mathrm{CD}-$ cow dung $\left(0,1\right.$, and $2-0 \mathrm{t}, 4 \mathrm{t}$ and $\left.8 \mathrm{t} \mathrm{ha}^{-1}\right)$

F- NPK 20-10-10 (0, 1 and 2- $0 \mathrm{Kg}, 150 \mathrm{Kg}$ and $\left.300 \mathrm{Kg} \mathrm{ha}^{-1}\right)$

\section{Discussion}

The integrated application of cow dung and NPK 20-10-10 positively impacted on the nodulation by the cowpea varieties. However, the higher rate of cow dung and high rate of NPK 20-10-10 did not lead to increase in nodulation by the cowpea varieties. The same trend was observed by the work of Olatunji and Anjembe, 2011 in their work with integration of poultry manure and NPK 20-10-10. The capacity of cowpea varieties to assimilate soil $\mathrm{N}$ may have been a major determinant of the nodulation count observed, which suggested that the higher the soil $\mathrm{N}$ in terms of mineral fertilizer, the lower the nodulation count that was obtained which agreed with earlier work by Rhodes, (1981) and Ofori (1973), that obtained that nodulation in cowpea was inhibited by application of $\mathrm{N}$ fertilizer. The high rates cow dung without NPK 20-10-10 produced better nodulation than combined integration of the high rates of cow dung and NPK 20-10-10. The implication of this was that the higher rates of manure applied did not release extremely high amount of soil- $\mathrm{N}$ that may have interfered with cowpea nodulation, hence the favorable result that was obtained. In terms of nutrient effect on nodulation, the negative effect was more pronounced on variety IAR 1060 than ITAS EARLY which suggested varietal difference as earlier observed by Olatunji and Anjembe, 2011 in their work that varietal difference is an important factor in legume nodulation.

The results obtained from this research study in terms of combined application of cow dung and NPK 20-10-10 on the amount of $\mathrm{N}$-fixed by cowpea varieties followed the same trend under nodulation that the high rate of cow dung in combination with high rate of NPK 20-10-10 will not lead to increase in cowpea fixation.

The highest N- Fixed at 6 WAP for 2008 and 2009 were $38.65 \mathrm{~kg} \mathrm{ha}^{-1}$ and $42.51 \mathrm{~kg} \mathrm{ha}^{-1}$ for variety ITAS EARLY and for IAR 1060 it was $34.68 \mathrm{~kg} \mathrm{ha}^{-1}$ obtained from the high rate of cow dung and not form the high rate of NPK 20-10-10, which implies that there is probably threshold fertilizer application that will not necessarily affect $\mathrm{N}$-fixation. Ojiem et al. (2007) in their findings observed declining $\mathrm{N}_{2}$ fixation with declining soil fertility status but Danso and Eskew (1984) asserted that when legumes are grown in soil high in available nitrogen, the nitrogen fixation rate is reduced. The $\mathrm{N}$ - fixed by cowpea variety (IAR1060) may be attributed to the genotypic differences of the cowpea varieties used in this study. The work of Ojiem et al.(2007) asserted that the amount of $\mathrm{N}_{2}$ fixed by a legume crop varies widely because it depends on the legume genotype, rhizobium strain and the soil environment.

In conclusion in order to identify legume species that will be tolerant to the use of combined fertilizer in terms of mineral fertilizer, organic manure in cropping system that involve legumes as biological $\mathrm{N}$-fixed. The amount of N-fixed will be an important factor that will help to identity the desirable variety of choice. 
The earlier work of Olatunji and Anjemte 2011 has provided information on the choice of cowpea tolerance to nutrient in terms of $\mathrm{N}$-fixation. This work therefore, corroborates their, finding that cowpea (ITAS EARLY) is high tolerant compare to cowpea (IAR 1060) inspite of the modification made in terms of nutrient sources combination.

\section{References}

[1]. AOAC,(1990). Official methods of analysis. Association of official analytical chemists Washington DC, pp 123-126

[2]. Bationo, A, Ntare , B.R, Tarawali, S.A.Tab, R. (2003). Soil fertility management and cowpea production in the semi arid tropics. In: cowpea contribution to farming systems/ Agronomic improvement of cowpea production (eds) Bation, A, Ntare , B,R, Tarawali, S,A and Tabo R Wiley. London, pp. 301- 318.

[3]. Balasubramanian, V.and Blaise, N.K.A (1993) short season fallow management for sustainable production in Africa, P.279-293. In J. Ragland and R.Lai (ed) Technologies for sustainable agriculture n the Tropics ASA spec. Publ. 56 ASA, CSSA and SSSA, Madison, W.T,

[4]. Bouyoucos, G.S (1951). A re- calibration of hydrometer method for mechanical analysis of soil, Agronomy Journal 43:434-438

[5]. Bray, R,H and Kurtz, L.T(1945). Determination of total organic and available forms of phosphorus in soil. Soil science.59:3945.

[6]. Bremner, J.M. and Mulvaney, C.S. (1982). Total nitrogen in Methods of soil Analysis $2^{\text {nd }}$ ed A.L page et al, (Eds) Pp 595- 624 ASA, SSSA Madison, Wisconsin.

[7]. Cheng, Q. (2008) Perspectives in biological nitrogen fixation research. Journal of integrative plant Brology $50:$ (7) : $784-796$

[8]. Danso, S.K.A and Eskew, D.L. (1984). Enhancing biological nitrogen fixation IAEA Bulletin Vol .26 No 2.Pp 29 -35

[9]. Franzluebbler, K. Juo , A.S.R and Manu, A. (1994). Decomposition of cowpea and millet amendments to a sandy Alfisol in Niger. Plant soil 167:225 - 265.

[10]. Galiba,M, Vissoh, P., Dagbenobakin, G. and fagbehoun, F. (1997) Reflexions et apprehensions paysannes lies a la velgarisation dupois masacate (Muluna ulilis) au Benin. Sasakawa Africa Association , Mexico city.

[11]. Hauser, S . (1990) Estimation of symbiotically fixed nitrogen using s extended N difference Methods. In biological Nitrogen Fixation and sustainability to Tropical Agriculture. Mulongoy Gueye and spencer (eds) Pp. 309 - 321.

[12]. IITA, (1995). Internation institute of Tropical Agriculture. Annual Report.

[13]. Kwesiga, F, Coe ,R, and Amate, M (1998). The effect of shot rotation. Sesbania sesiban planted follow .on maize yield. For Ecol. Manage. 64:199-208

[14]. Manyong, V, M, Houndekon, A.V and Kergna,s. (1997) “ Land tenurial systems and the adaptation of mucuna planted fallows in the derived savanna of west Africa" paper presented at the workshop on property Rights, collective Action and Technology Adoption . ICARDA. Nov, 22.25 Aleppo, Syria.

[15]. Nambiar, P, T.C, Rao ,M.R, Raddy, M.S, Floyd, C.N, D art, P.J and willey, R.W. (1983) Effect of intercropping on nodulation and $\mathrm{N}_{2}$ - Fixation by groundnut. Exp Agric 19:79-86.

[16]. Ofori, C.S. (1973). The importance of fertilizer nitrogen in granitic origin in the upper region of whan. In proceedings of first IITA Crain legume improvement workshop 1973, pp: $155-161$.

[17]. Oijiem .O. Vanlavwe B, de Ridder ,N, Geller, K.E (2007) Niche based assessment of contribution of legumes to the nitrogen economy farms plant soil. 292:119 -1135.

[18]. Olatunji, O and B.C. Anjermbe (2011). Effects of Enriched Organic Manure an N - fixed Ability of cowpea (Vigna unguiculata (L) Walp) grown in maize mixture. Agro Science Journal of Tropical Agriculture, food, Environment and Extension. Vol.10 Nm, 3 pp $13-21$

[19]. Osei - Bonsu, P and Buckles, D (1993) Controlling weeds and improving soil fertility through the use of cover crops. Experience with Mucuno Spp. In berin and Ghana P.277. In west Africa farming syst. Res. Network Bull. 14 Inst of Trop. Agric. Ibadan, Nigeria.

[20]. Rhodes,E.R (1981). The economic of fertilizing cowpea (Vigna unguiculaata (L) Walp) with basic slag on an oxisol in Njala and the effect on the fertilizer on leaf lamina, N, P, Zn contents and nodulation. Trop. Grain Legume Bull 22:6-10

[21]. Shumba, E,M., Dhilwayo, H.H and Mukoko, O. Z (1990). The potential of maize cowpeaintercropping in low rainfall areas of Zimbabwe. Zimbubwe. J. Agric. Res 2:33-38Szott, L, T, Palm, C.A and Buresh , R. J (1998). Ecosystem fertility and fallow function in R.J. Buresh and P.J cooper (ed). The science and Practice of short term improved fallows. Kluwer Acodemic Publ. Dordercht, the Netherlamds.

[22]. Walkey, A and Blank, C.A (1934). An Examination of the Degtjareff method for determining soil organic matter and a proposal modification of chronic acid titration method. Soil sci. 37: 29 - 38 